Hipotenusa : Journal of Mathematical Society

Volume 3 Issue 1 Year 2021

ISSN: $2716-3156$

Website: https://hipotenusa.iainsalatiga.ac.id/index.php/hipotenusa/index

\title{
Effect of Math Anxiety and Motivation Against Student Mathematical Connections Capabilities
}

\author{
Haerudin $^{1 *}$, Dewi Anjani ${ }^{1}$, Didymus Ibrahi ${ }^{2}$ \\ ${ }^{1}$ Universitas Singaperbangsa Karawang, Indonesia \\ ${ }^{2}$ Kisii University, Kenya \\ *Corresponding Author, e-mail: haerudin@fkip.unsika.ac.id \\ DOI: 10.18326/hipotenusa.v3i1.52-79
}

\begin{abstract}
Article submitted : January 12, 2021
Article reviewed : March 26, 2020

Article published : June 1, 2021
\end{abstract}

\begin{abstract}
This study aims to determine the effect of mathematics anxiety and learning motivation on students' mathematical connection abilities. This research was conducted in SMP Negeri 1 Cikampek class VII 9. In the selection of research samples using the cluster random sampling technique. With the method of Correlational research type of regression, the data used are quantitative data obtained from the inquiry questionnaire and learning motivation and mathematical connection ability test questions. Data processing techniques used in this study are using multiple linear regression. In this study quantitative data processing was performed using IBM SPSS 21.0 software for windows. The results of this study obtained a regression equation $\mathrm{Y}=-58,623+0,678 \mathrm{X}_{1}+0,359 \mathrm{X}_{2}$ which is linear with a determination coefficient of $30.3 \%$, meaning that about $69.7 \%$ is explained outside of the regression equation. Thus, it was found that mathematics anxiety and learning motivation significantly influence students' mathematical connection abilities.

Keywords: mathematics anxiety, learning motivation, mathematical connection
\end{abstract}

\section{INTRODUCTION}

Law Number 20 of 2003 concerning the National Education System shows that "education is a conscious and planned effort to create a learning and learning atmosphere so that students actively develop themselves to have spiritual strength, self-control, personality, intelligence. , noble character, and skills needed by him, society, nation, and state". In the world of education, many sciences can be included, one of which is mathematics. National education places mathematics as one of the subjects at the educational unit level. It is undeniable that our daily lives cannot be separated from mathematics. 
Thus directing students in learning mathematics is important so that understanding the concepts that will be needed to solve mathematics and other sciences (Setiana et al., 2020; Tomperi et al., 2020). For this reason, students need to have mathematical abilities.

One of the mathematical abilities that students must have is the ability to connect mathematically. Mathematical connection ability can be used as a goal of learning mathematics. According to NCTM states that mathematical connection ability is a goal in mathematics learning that must be achieved by students in understanding mathematical concepts, explaining the relationship between concepts, and using these concepts in solving problems or problems (Abade et al., 2019; Hunsader et al., 2013; Prayitno, 2018; Shuhan, 2006). Therefore, mathematical connection skills are essential for every student to master.

The above conditions are reinforced by the results of observations made by researchers that the mathematical connection abilities of students in one of the junior high schools in Karawang can be categorized as a medium for superior classes but for nonsuperior classes are still categorized as low in line with research conducted by Anjani \& Imami (2020) which states that the ability of mathematical connections is low, the category is low in linking mathematics in everyday life. This happens because most students just want to finish working on the questions quickly regardless of correct or incorrect answers, and some students do not want to find out the process of getting a concept from the material being taught.

In other words, if students have good mathematical connection skills, these students master or memorize formulas in the short term and apply them in solving other problems. Mathematical connection indicators used in this study According to Hendriana et al. (2017), it is stated that the mathematical connection ability indicators include: 1) Looking for relationships between various representations of concepts and procedures, and understanding concepts between mathematical topics. 2) Understanding the equivalent representation of the same concept, looking for a connection from one procedure to another in an equivalent representation. 3) Using the various representations of concepts and procedures. 4) Using mathematics in other fields of study or everyday life. 5) Using and assessing the relationship between mathematics topics and the relation of mathematical topics to topics outside mathematics. 
The teaching and learning process can be influenced by various factors, one of which is the anxiety factor of the assumption that mathematics is a frightening subject and that fear creates anxiety when students learn and interact with mathematics, or it is known as mathematics anxiety. Tobias (1993) defines math anxiety as feelings of tension and anxiety that interfere with number manipulation and mathematical problem solving in a variety of situations of everyday life and academic situations (Kirkland, 2016; Pizzie et al., 2020). Students who experience anxiety about mathematics feel that they are unable and unable to study mathematics material and work on math problems. Stuart (2006) states that the common symptoms of math anxiety are often marked as 1) Somatic: Shaking, heart palpitations, excessive sweating, abdominal pain or nausea, shortness of breath, difficulty speaking, fatigue, feeling tense, cold hands, headache . 2) Paikologist: Worried, Difficult to concentrate, Want to run away, Looking for busyness (restlessness), Fear, Can't sleep.

In addition to the anxiety factor, there are other factors that can influence the learning process that are no less important, namely the learning motivation factor that will underlie students in carrying out learning activities, in understanding the material provided by the teacher. According to Badaruddin, Mustamin Anggo, dan Makkulau (2019) stated that learning motivation is very important for students in solving mathematical problems, especially in connecting learning. But in fact, in the learning process, it shows that students' learning motivation is not good or low (Podkalicka, 2011; Sancho-Vinuesa \& Gras-Martí, 2010; Utami et al., 2020). According to Am (2011) states that motivation includes: a) Persevering in facing tasks. b) Resilient in facing adversity. c) Shows interest in various problems. d) Happier working independently. e) Quickly get bored of routine tasks. f) Can defend his opinion. g) Not quickly released from what is believed. h) Happy to find and solve complex problems. However, given the current condition of the COVID-19 pandemic in Indonesia, it has an impact not only on the life sector but education. According to Kompas (28/03/2020), the effect of the COVID-19 virus occurred in various fields such as social, economic, tourism and education (Dewi, 2020). On March 24, 2020, the Minister of Education and Culture of the Republic of Indonesia issued Circular Number 4 of 2020 concerning the implementation of education policies in the emergency period of the spread of COVID-19. In the letter, it was explained that learning processes were carried out at home through online / distance 


\section{Hipotenusa Journal, 3 (1), June 2021}

Haerudin, Dewi Anjani, Didymus Ibrahi

learning. So the researchers conducted research online. Based on the explanation above, the research objective is that there is an influence between mathematics anxiety on students' mathematical connection ability, there is an influence between learning motivation on students' mathematical connection ability, knowing there is an influence between mathematics anxiety and learning motivation on students' mathematical connection ability.

\section{METHOD}

The method used in this study was correlational research, because the researcher wanted to know the direction of the relationship and the influence of the variables. The direction of the relationship and the effect of the variables observed were mathematics anxiety, learning motivation and students' mathematical connections. The correlational design, in brief, the correlational design, can be described as follows.

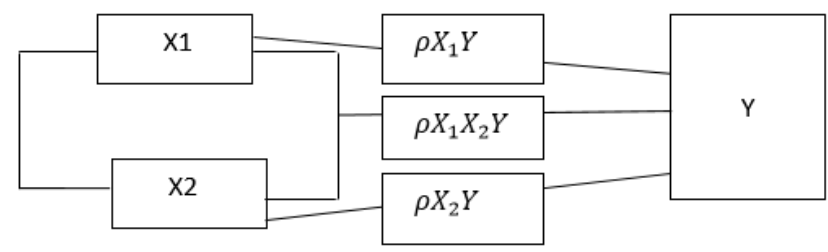

Figure 1. Correlational design in this research

Information:

$X_{1} \quad$ : Mathematics Anxiety

$X_{2} \quad$ : Learning Motivation

Y : Mathematical Connection Capability

$\rho X_{1} Y \quad$ : Mathematical Worries of Connection Ability

$\rho X_{2} Y \quad$ : Learning Motivation on Connection Ability

$\rho X_{1} X_{2} Y \quad$ : Mathematics Anxiety and Learning Motivation Against Mathematical Connection Ability.

According to Sugiyono (2016), population is a generalization area consisting of objects/ subjects that have certain qualities and characteristics that are applied by researchers to study and then draw conclusions. The sample subjects of this study were all class VII in Karawang district, namely SMP Negri 1 Cikampek. The sampling 
technique used was the cluster random sampling technique. In that SMP, 1 class was selected, namely VII.9.

The data collection technique used in this study was to use the test description method and questionnaire, the purpose of the essay test was to determine the ability of students 'mathematical connections and the purpose of distributing questionnaires to determine students' math anxiety and student learning motivation to influence the connection or not. The instrument is used after validation by the validator and then declared valid and fit for use.

\section{RESULTS AND DISCUSSION}

The data used are quantitative data obtained from the test results of mathematical connection ability, mathematics anxiety, and learning motivation. Quantitative data processing was done using IBM SPSS 21 For Windows Software. The results obtained are as follows:

Table 1. Mathematical Anxiety Categories

\begin{tabular}{ccccc}
\hline No & Score & F & Percentage & Category \\
\hline 1 & $x>77,6$ & 7 & $17,5 \%$ & High \\
2 & $70,4<x \leq 77,6$ & 22 & $55 \%$ & Middle \\
3 & $x<70,4$ & 11 & $27,5 \%$ & Low \\
\hline & Total & 30 & $100 \%$ & \\
\hline
\end{tabular}

Based on Table 1, it can be seen that the mathematics anxiety category in the high category was seven students (17.5\%), the moderate category was 22 students (55\%), and the low category was 11 students $(27.5 \%)$.

Table 2. Learning Motivation Categories

\begin{tabular}{ccccc}
\hline No & Score & F & Percentage & Category \\
\hline 1 & $>90,6$ & 2 & $5 \%$ & High \\
2 & $54,4<x \leq 90,6$ & 5 & $12,5 \%$ & Middle \\
3 & $x<54,4$ & 33 & $82,5 \%$ & Low \\
\hline & Total & 40 & $100 \%$ & \\
\hline
\end{tabular}


Based on Table 2, it can be seen that the learning motivation category in the high category was two students (5\%), the moderate category was five students $(12.5 \%)$, and the low category was 33 students $(82.5 \%)$.

Table 3. Mathematical Connection Categories

\begin{tabular}{ccccc}
\hline No & Score & F & Percentage & Category \\
\hline 1 & $x>32,6$ & 9 & $22,5 \%$ & High \\
2 & $18,3<x \leq 32,6$ & 13 & $32,5 \%$ & Middle \\
3 & $x<18,3$ & 18 & $45 \%$ & Low \\
\hline & Total & 40 & $100 \%$ & \\
\hline
\end{tabular}

Based on table 3, shows that the mathematical connection category in the high category is nine students $(22.5 \%)$, the medium category is 13 students $(32 \%)$, the low category is 18 students (45\%).

After obtaining the results of the high, medium, low categorization values, then conducting a prerequisite analysis is carried out to find out the data collected meets the requirements for analysis using statistical techniques. The prerequisite test includes the normality test, linearity test, multicollinearity test, and heteroscedasticity test. The results of the analysis requirements test in the study are presented as follows:

Table 4. Normality Test

\begin{tabular}{cc}
\hline Significant value & Description \\
\hline 0,22 & $H_{0}$ Accepted
\end{tabular}

Based on the results of the normality test output using Shapiro Wilk in Table 4, it shows that the data has a significance value $>0.05$ with the information $\mathrm{H}_{0}$ is accepted, which means that the data on mathematics anxiety, learning motivation and connection ability are normally distributed. 


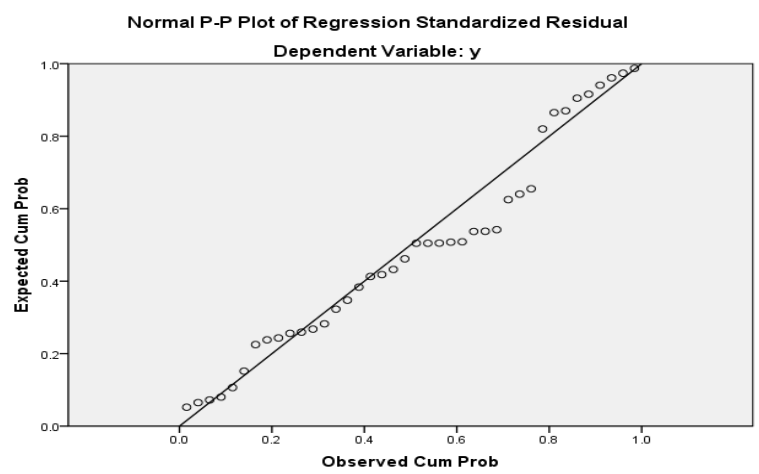

Figure 2. Normal P-P plot

Based on Figure 2 shows that the point (plot) on the normal P-P plot is close to the normal line, meaning that the data on anxiety, learning motivation, and connection ability is normally distributed. Because the data is normally distributed, the next step is the linearity test.

Table 5. Linearity Test

\begin{tabular}{rlcccc}
\hline No & \multicolumn{1}{c}{ Variable } & Sig & Alpha & Description \\
\hline 1 & $\begin{array}{l}\text { Math anxiety effect on the ability of } \\
\text { students' mathematical connection }\end{array}$ & 0,08 & 0,05 & Linear \\
2 & $\begin{array}{l}\text { Learning motivation influence on the } \\
\text { ability of students mathematical } \\
\text { connection }\end{array}$ & & & Linear \\
\end{tabular}

Table 5 above, shows that the sig.linearity value is $0.08>0.05$ and $0.48>0.05$. So it can be concluded that Ho is accepted or, in other words, the distribution of linear data (two variables have a linear relationship).
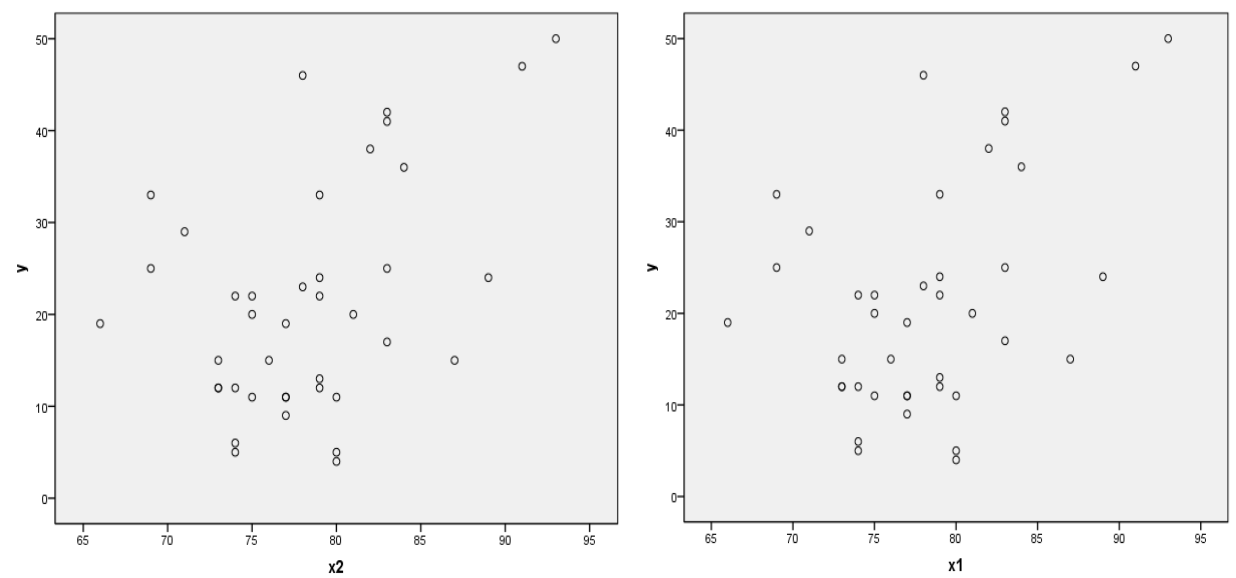

Figure 3. Linearity 


\section{Hipotenusa Journal, 3 (1), June 2021}

Based on the scatter plot graph above, it can be seen that the data plot points form a straight free pattern from the bottom left upwards. This shows that there is a linear and positive relationship between the variable mathematics anxiety $\left(\mathrm{X}_{1}\right)$ and the mathematical connection variable. This positive relationship means that if mathematics anxiety is high, the ability of the mathematical connection will be weak. A linear and positive relationship between the learning motivation variable $\left(\mathrm{X}_{2}\right)$ and the mathematical connection variable, this positive relationship means that if learning motivation increases, the ability of the mathematical connection will also increase.

Table 6. Mulicollinearity Test

\begin{tabular}{cccc}
\hline Variabel & Tolerance & VIF & Conclusion \\
\hline$X_{1}$ & 1,000 & 1,000 & Multicollinearity does not occur \\
$X_{2}$ & 1,000 & 1,000 & Multicollinearity does not occur \\
\hline
\end{tabular}

Table 6 above shows that the VIF value of mathematics anxiety is $1.137<10.00$ and the tolerance value is $0.880<0.10$, which refers to the basis of decision-makers in the multicollinearity test, so there is no multicollinearity and the VIF value. Learning motivation is $1.137<10.00$, and the value tolerance $0.880<0.10$ refers to the basis of decision-makers in the multicollinearity test, so there is no multicollinearity. The next analysis is the heteroscedasticity test.

Table 7. Heteroscedasticity Test Results

\begin{tabular}{ccc}
\hline Variable & Significant value & Information \\
\hline $\mathrm{X}_{1}$ & 0,040 & there is no heteroscedasticity \\
$\mathrm{X}_{2}$ & 0,023 & there is no heteroscedasticity \\
\hline
\end{tabular}

Table 7 above, for the anxiety variable $\left(\mathrm{X}_{1}\right)$ is 0.040 while the learning motivation variable $\left(\mathrm{X}_{2}\right)$ is 0.023 . Because the significance value $<0.05$, according to the basis of the decision, it can be concluded that there is no heteroscedasticity in the regression model. 


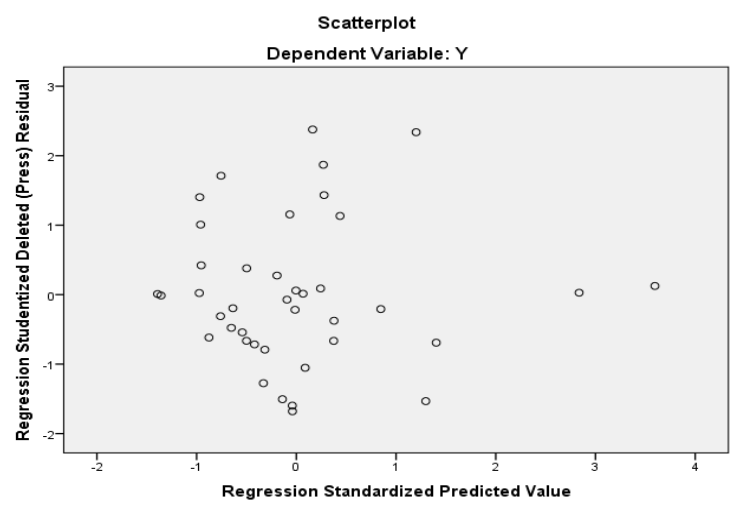

Figure 4 Heteroscedasticity Test Results

Figure 3 above shows that the points on the scatterplot do not form a certain pattern or do not converge at one point, so the data does not have heteroscedasticity. Next is hypothesis testing. Hypothesis testing in this study uses multiple linear regression analysis.

Table 8. Multiple Regression Output

Coefficients $^{\mathrm{a}}$

\begin{tabular}{|c|c|c|c|c|c|}
\hline \multirow[t]{2}{*}{ Model } & \multicolumn{2}{|c|}{ Unstandardized Coefficients } & \multirow{2}{*}{$\frac{\text { Standardized Coefficients }}{\text { Beta }}$} & \multirow[t]{2}{*}{$\mathrm{t}$} & \multirow[t]{2}{*}{ Sig. } \\
\hline & B & Std. Error & & & \\
\hline (Constant) & $-58,623$ & 23,332 & & $-2,513$ & 016 \\
\hline $1 \times \_1$ & ,678 & ,319 & 3 & 2,124 & ,040 \\
\hline X_2 & ,359 & 151 & 3 & 2,378 & ,023 \\
\hline
\end{tabular}

\section{The effect of math anxiety on students' mathematical connection abilities}

The results showed that there was a positive influence on mathematics anxiety on students' mathematical connection abilities. This is shown based on the results of the partial calculation of the effect of mathematics anxiety on students' mathematical connection ability, the regression correlation coefficient (b) is 0.678 . significant value (p) $<0.05$, then the first hypothesis "There is a significant effect of mathematics anxiety on students' mathematical connections" is accepted, the higher the students' mathematics anxiety, the lower the students' mathematical connection learning outcomes.

Based on the results of testing hypothesis 1 that had been done previously, it was found that the student mathematics anxiety variable influenced the students' mathematical connection ability.

In terms of the quality of the answers to each statement item related to the somatic indicators of answers given by respondents, the percentage is $65 \%$ and the psychological 
percentage is $43.75 \%$, students often feel bodily and psychological symptoms in the learning process, especially in learning mathematics. Questions related to the ability to connect indicators to find relationships between various representations of concepts and procedures, as well as understanding concepts between mathematical topics, the total score of the answers given by respondents is a percentage of $40 \%$, students indicate tension and a sense of inadequacy, want to run away not to do questions, this can be seen from the results of the student's answers, he was not able to solve the questions properly, this was due to the presence of somatic and psychological symptoms which were quite significant affecting students in the process of understanding the answers as seen from the students' answers.

Unable to understand the answers correctly, even the student did not answer correctly according to the concepts and procedures are given. This means that students have a high average somatic symptom, this affects the mathematical connection ability of students, as well as students who have a high enough average psychological symptom this will affect their mathematical concussion ability. It has a positive effect but gets pretty good results. The question indicator has the equivalent representation of the same concept, looking for a connection from one procedure to another in an equivalent representation, the answer is given by the respondent's percentage of $80 \%$ and the respondent's psychological statement. These students experience These symptoms when understanding the questions given by students feel inadequate. This can be seen from students' incomplete answers, the difficulty of students' concentration in understanding the questions, and fear due to the inability to understand the questions well. This means that students who have high anxiety and high connections have a positive effect

Furthermore, based on the students' answers to the questions using the relationship between conceptual representation and procedures in applying the concept of circumference, the answer was given by the respondent with a percentage of $25 \%$ and the percentage of respondents with somatic statements by $65 \%$ and psychological by $43.75 \%$, in learning somatic and psychological symptoms greatly affect students, due to somatic and psychological symptoms students are not able to apply the concept of the perimeter and area of the triangle properly. This can be seen from the answers of students who are only able to answer known and asked somatic symptoms affect students' processes 
applying the answers. This means that students have high somatic symptoms and the ability to apply low concepts. It has a positive influence but gets negative results.

Furthermore, based on students' answers to statements using mathematics in other fields of study or daily life, the percentage of answers given by respondents is a percentage of $25 \%$. For respondents with somatic statements, the percentage is $65 \%$. Psychological is $43.75 \%$, these percentages identify that in learning somatic symptoms and psychologically very influences students, due to somatic and psychological symptoms students are not able to solve daily problems using the properties of the rectangle properly, this can be seen from the answers of students who are only able to answer known and asked only because in the process students feel the pressure so that the results were not optimal, it was seen that somatic and psychological symptoms affected the students' pores in completing the answers. This means that students have high somatic symptoms and the ability to use mathematics in everyday life is low. It has a positive influence but gets negative results.

The indicator uses and assesses the linkage of mathematics between mathematical topics and non-mathematics topics in applying the concept of perimeter and area of the triangle. The answers given by respondents are a percentage of $40 \%$, and respondents with somatic statements are $65 \%$ and psychologically $43.75 \%$ in learning somatic and psychological symptoms. It greatly affects students, due to bodily and psychological symptoms, students are not able to apply the concept well, this can be seen from the answers of students who are only able to answer being unable to apply existing concepts, lack of concentration, feeling like running away when getting math problems, tense when learning takes place. This seems to affect students' processes to apply the concept of answers. This means that students have a high average somatic symptom, this affects the mathematical connection ability of students, as well as students who have a high enough average psychological symptom, this will affect the concise skills in applying mathematical concepts. It has a positive influence but gets pretty good results.

The findings above show that each indicator of students' mathematical connection ability is influenced by somatic and psychological symptoms simultaneously, although in this case, the level of influence is trim. It could be other variables that more influence the mathematical connection indicator. 
This research is in line with the results of research conducted by Fista et al. (2019) entitled "The Effect of Mathematical Anxiety on the Mathematical Connection Ability of Class VII MTsN 4 Pasma Barat Students." Mathematical anxiety on mathematical connection ability is due to the low and moderate level of student anxiety, so this equation is able to predict students 'mathematical connection ability at low and moderate levels of students' math anxiety.

\section{The influence of learning motivation on students' mathematical connection abilities}

The results showed that there was a positive effect of learning motivation on students' mathematical connection abilities. This is shown based on the partial calculation of the effect of mathematics anxiety on students' mathematical connection ability, the regression correlation coefficient (b) is 0.359 . At the $5 \%$ significant level, it can be seen that $t_{-}$count is 2.378 with a significant value of 0.023 because the regression coefficient has a positive value and Significant value (p)>0.05, the second hypothesis "There is a significant effect of learning motivation on students' mathematical connections" is accepted, the higher the student's learning motivation, the higher the student's mathematical connection learning outcomes.

Based on the results of testing hypothesis 2 that had been done previously, it was found that the student learning motivation variable influenced the students' connection ability. In terms of the quality of the answers to each statement item related to indicators of being diligent in facing the answer score task given by the respondent, the percentage is $84 \%$ and questions related to the ability of the indicator connection look for relationships between various representations of concepts and procedures, as well as understanding concepts between mathematical topics. The percentage given by the respondent is $40 \%$, this percentage indicates that the student responds to the assignment given related to mathematical connection questions, but when given the assignment to be done individually, the student is unable to understand in connecting the questions given and does not complete it with good. This means that the persistence indicator positively affects students' ability to find relationships between topics and understand the concepts between topics even though the results obtained are still in the sufficient category.

The question indicator has the equivalent representation of the same concept, looking for a connection from one procedure to another in an equivalent representation, the percentage of answers given by respondents is $80 \%$, and the respondent's statement 
of being diligent in facing the task is $84 \%$, this percentage indicates that students respond to the task given in relation to it. Mathematical connection questions, when given assignments to be done individually, students are very enthusiastic and fast in collecting their assignments, and the results are good according to the concepts and procedures in connecting math problems. This means that the attitude of being diligent in facing the task has a positive effect on the ability to understand the concept of the same equivalent. The results can be classified in the high category, meaning that it has an equally positive effect.

Furthermore, based on the students' answers to the questions using the relationship between conceptual representation and procedures in applying the concept of circumference, the percentage of answers given by the respondent is $25 \%$, and the respondent's statement of being diligent in facing the task is $84 \%$, this percentage indicates that the student responds positively to the assignment given regarding the questions. Mathematical connection, when given a task to be done individually, the student was not able to apply the concept of the circumference properly. It was seen from the answers that the students produced answered questions carelessly. This means that the indicator of being diligent in facing the task has a positive effect, but the students' ability to use the relationship between the representation of concepts and procedures is still in the low category, has a positive effect but gets negative results.

Based on students' answers to statements using mathematics in other fields of study or daily life, the percentage of answers given by respondents is $25 \%$. Respondents are statements of being diligent in facing the task with a percentage of $84 \%$, this percentage indicates that students respond positively to the assignment given through questions -the problem of mathematical connections, when given assignments to be done individually, students are very enthusiastic and fast in collecting their assignments. The results of their work do not fit the concepts and procedures well. This means that the indicator of being diligent in facing tasks has a positive effect, but the ability of students to use mathematics in their daily life is still in the low category; this has a positive effect but a negative result.

Finally, the motivation indicator uses and assesses the relationship between mathematics topics and non-mathematics topics in applying the concept of perimeter and area of the triangle. The answers given by respondents are a percentage of $40 \%$, and respondents with somatic statements have a percentage of $84 \%$; this percentage indicates 
that students respond positively to the assigned task. Regarding mathematical connection questions, students were quite enthusiastic and quite fast in collecting their assignments when given assignments to be done individually. The results of the work were in accordance with the concept but not in accordance with the application of the connecting procedures. This means that the indicator of being diligent in facing assignments has a positive effect, but the ability of students to use and assess the relationship between mathematics and mathematics topics is still in a fairly good category.

In terms of the quality of the answers to each statement item related to indicators of resilience in facing the difficulty of the answer given by respondents, the percentage is $80 \%$ and questions related to the ability of the indicator connection look for relationships between various representations of concepts and procedures, as well as understanding concepts between mathematical topics, the total score is obtained from the answers. The percentage given by the respondent is $40 \%$, this percentage indicates that students are serious when faced with difficulties, this can be seen when the teacher gives questions that must be solved related to mathematical connection problems, students are unable to understand the concept of mathematical topics properly, seen from the answers generated by the students answered the questions did not finish well. This means that the indicator of resilience in facing adversity has a positive effect but the result of the ability

The question indicator has the equivalent representation of the same concept, looking for a connection from one procedure to another in an equivalent representation, the percentage of answers given by the respondent is $80 \%$, and the resilient indicator faces the difficulty of the answers given by the respondent, the percentage is $80 \%$, this percentage indicates that students very serious when faced with difficulties, this can be seen when the teacher gives questions that must be resolved related to mathematical connection questions, students are able to understand the concepts between mathematical topics well, seen from the answers generated by students answering questions that are finished well.

Furthermore, based on the students' answers to the questions using the relationship between conceptual representation and procedures in applying the concept of circumference, the percentage of answers given by the respondent is $25 \%$, and the indicator of resilience in facing the difficulty of the answers given by the respondent is $80 \%$, this percentage indicates that students are very, very serious. Really when faced 
with difficulties, this can be seen when the teacher gives questions that must be solved related to mathematical connection questions, students are unable to apply the concept of circumference; this can be seen from the students' incorrect answers.

Based on students' answers to statements using mathematics in other fields of study or daily life, the percentage of answers given by respondents is $25 \%$, and the indicator of resilience in facing difficulties with answers given by respondents is $80 \%$, this percentage indicates that students are very, very serious When faced with difficulties, this can be seen when researchers provide individual questions that must be solved related to mathematical connection problems, students are not able to relate questions to everyday life, this can be seen from students' answers that do not match in connecting questions.

Finally, the motivation indicator uses and assesses the relationship between mathematics and non-mathematics topics in applying the concept of perimeter and area of the triangle, the percentage of answers given by respondents is $40 \%$, and the indicator of resilience in facing the difficulty of answers given by respondents is $80 \%$, this percentage indicates that students very very serious when faced with difficulties, this can be seen when researchers provide individual questions that must be solved related to mathematical connection questions, students feel they are able to apply the concept of circumference, this can be seen from the answers of students who have not finished well but the students wrong in linking problems outside of mathematics so that students are wrong in concluding the results obtained.

In terms of the quality of the answers to each statement item related to indicators showing interest in various problems, $66.25 \%$ and questions related to the ability of the indicator connection to find relationships between various representations of concepts and procedures, as well as understanding concepts between mathematical topics obtained a total score of The percentage of answers given by respondents is $40 \%$. This indicates that students have a high interest in learning; engaging learning provides a more pleasant atmosphere. This is shown at the time after the implementation of giving the questions individually connected to the student's answer connection. It shows that students are not able to complete it well, even though students have an interest in learning.

The question indicator has the equivalent representation of the same concept, looking for a connection from one procedure to another in an equivalent representation, the percentage of answers given by the respondent is $80 \%$, and the indicator shows an 
interest in various problems, $66.25 \%, \%$. This indicates that students have a high interest in learning; engaging learning provides a more pleasant atmosphere. This is shown at the time after the implementation of giving the questions individually connected to the student's answer connection, which shows that students are able to complete it well.

Furthermore, based on the students' answers to the questions using the relationship between conceptual representation and procedures in applying the concept of circumference, the answer given by the respondent is a percentage of $25 \%$, and the indicators show interest in various problems, $66.25 \%$, this indicates that students have a strong interest. High on learning, engaging learning provides a more pleasant atmosphere. This is shown at the time after the implementation of giving individual questions related to the connection of the student's answers, and it shows that the students are not able to solve them correctly because the students are not able to apply the existing concepts and procedures so that the students' answers are not correct.

Based on students' answers to statements using mathematics in other fields of study or everyday life, the answers given

The percentage of respondents is $25 \%$, and the indicators show interest in various problems, $66.25 \%$. This indicates that students have a high interest in learning, interesting learning provides a more pleasant atmosphere. This is shown at the time after the implementation of giving questions individually related to the connection of student answers; it shows that students cannot complete it properly because students cannot associate problems according to existing daily life so that the student's answer is not correct.

Finally, the motivation indicator uses and assesses the relationship between mathematics topics and topics outside mathematics in applying the concept of perimeter and area of the triangle. Respondents give the answers are $40 \%$ and $40 \%$ prefer to work independently. This indicates that students have a high interest in learning. Engaging learning provides a more enjoyable atmosphere. This is shown at the time after the implementation of giving individual questions related to the connection of student answers, it shows that students are not able to complete and use relationships outside mathematics properly so that the results obtained are not satisfactory.

In terms of the quality of the answers to each statement item related to indicators on indicators, they prefer to work independently with a percentage of $40 \%$ and questions 
related to the ability of the indicator connection to look for relationships between various representations of concepts and procedures and to understand concepts between mathematical topics, the total score of the answers given The percentage of respondents was $40 \%$. This indicated that students carrying out connection questions online said that it was better to work on the questions independently because, according to him, collaborating with friends online was not effective. So, it can be said that students prefer to work independently to achieve better goals.

A percentage of $23.75 \%$ occurs in indicators of getting bored quickly on routine tasks. Based on this percentage, it can be concluded that students like learning with a new atmosphere; this is because according to the assumption of students learning that is often applied by the teacher is always monotonous and boring. So when given questions related to mathematical connections students have difficulty linking, applying, and using existing concepts so that they affect student learning.

On indicators that can defend their opinion, student respondents have a percentage of $60 \%$. In this indicator, it can be seen in the learning process when competing to complete a mission that there are students who regret that they have followed their friends' opinions, which apparently did not give good results. It is clear that these students become more able to defend their opinions when working on math problems.

The indicators regarding students are not easy to let go of things that are believed to have increased by $80 \%$. This is the same as the indicator of being able to defend their opinion; students feel afraid if they experience failure again in solving connection questions; therefore students are more consistent with what they have believed.

The percentage of indicators of students who are happy to find and solve complex problems is $53 \%$. The percentage of this increase is seen from the enthusiasm of students when looking for and solving mathematical connection problems on a given mission, and not only that the enthusiasm of students in completing connections can be seen from the results of good answers with a reasonably good score as well, it affects student connections.

Based on the description of some of the indicators above, it can be seen that student learning motivation can grow with encouragement from inside or outside, with motivation students will be more enthusiastic in learning, especially in connecting mathematics. This is consistent with what was said by Mc. Donald students are said to have motivation in 
learning if there is a change in energy in the student because of a response to the goals achieved, the goal here is that students understand and are able to connect well.

Based on some of the explanations above, it can be said that there is an effect of learning motivation on students' mathematical connection abilities.

The results of this study are in line with the results of research conducted by Badaruddin, et al. (2019) The Effect of Learning Motivation on Students 'Mathematical Connection Ability. "It shows that learning motivation with students' mathematical connection ability is $25.5 \%$, the positive effect of learning motivation on mathematical connection abilities is due to motivation. Student learning is still relatively low, so this equation is able to predict the ability of students to connect mathematically at a low level of student motivation.

The Influence of Mathematics Anxiety and Learning Motivation on Students' Mathematical Connection Ability.

The results showed a positive influence on mathematics anxiety and learning motivation simultaneously on students' mathematical connections. This is shown based on the results of the simultaneous calculation of the effect of mathematics anxiety and learning motivation on students' mathematical connection abilities, at the $95 \%$ significance level, it can be seen that $F_{\text {count }}$ is 8.054 with a significant value of 0.01 because the regression coefficient has a positive value and a significant value $(\mathrm{p})<0.05$, the third hypothesis "There is a significant effect of mathematics anxiety and learning motivation on students 'mathematical connection abilities" is accepted. This means that the variables of mathematics anxiety and learning motivation on mathematical connection abilities have a significant effect on students' mathematical connection abilities.

The results showed that there was a positive influence on mathematics anxiety and learning motivation simultaneously on students' mathematical connections

In terms of the quality of the answers to each statement item related to somatic symptoms the response of the student's answer, the percentage is $65 \%$. The indicator is diligent in facing the answer score task given by the respondent, the percentage is $84 \%$ for questions related to the ability to connect indicators to find relationships between various representations of concepts and procedures, and understand The concept between mathematics topics is obtained by a total score of the answers given by respondents, a percentage of $40 \%$, this percentage indicates that students experience problems when given tasks related to mathematics, even though the student responds to the assignment 
given related to mathematical connection questions. However, in When given an assignment to be done individually, the student is unable to understand in connecting the questions given and does not complete it properly because students experience disruption during the learning process. This means that somatic and diligent indicators positively affect students' ability to find relationships between topics and understand concepts between topics even though the results obtained are still in the sufficient category.

Indicators related to somatic symptoms respond to student responses; the percentage is $65 \%$. The respondent's statement of being diligent in facing the task is $84 \%$, for the question of understanding the equivalent representation of the same concept, looking for a connection from one procedure to another in an equivalent representation, the percentage of answers given by the respondent is $80 \%$, This percentage indicates that students respond to the assignment given related to mathematical connection questions. However, when given tasks to be done individually, students experience somatic symptoms, this does not reduce enthusiasm and speed in collecting their assignments and the results are good according to the concepts and procedures in connect math problems. This means that even though students experience somatic symptoms, it does not significantly affect it because the attitude of being diligent in facing the task has a positive effect on the ability to understand the concept of the same equivalents, the results can be classified in the high category, meaning that it has an equally positive effect.

Furthermore, related to somatic symptoms, the percentage of student responses is $65 \%$. The respondent's statement is diligent in facing the task of $84 \%$, to the question using the relationship of conceptual representation and procedures in applying the concept of circumference, the percentage of answers given by respondents is $25 \%$, this percentage indicates that learning mathematics experiences symptoms somatic level but the enthusiasm of the students responded positively to the assignment given related to mathematical connection questions. However, when given the assignment to be done individually, the student was not able to apply the concept of circumference well, it was seen from the answers produced by the students answering the questions with the origin -as a reason this is due to somatic symptoms which are so significant affecting students. This means that somatic indicators and indicators of being diligent in dealing with tasks have a positive effect. However, the students' ability to use the relationship between 


\section{Hipotenusa Journal, 3 (1), June 2021}

Haerudin, Dewi Anjani, Didymus Ibrahi

representation of concepts and procedures is still in the low category, has a positive effect but gets negative results.

Based on student answers related to somatic symptoms, the percentage of student responses is $65 \%$. The percentage of respondents who are diligent in facing tasks with a percentage of $84 \%$, for statements using mathematics in other fields of study or daily life, the percentage of answers given by respondents is $25 \%$, this percentage indicates that students positively respond to the assignment given through mathematical connection questions. However, in doing the assignments given students still have difficulty due to significant somatic symptoms, it is proven that when given assignments to be done individually students are very enthusiastic and fast in collecting their tasks. However, students have difficulty working due to fear of mathematics so that the results of the work do not match the concepts and procedures properly. This means that indicators of math anxiety and indicators of being diligent in facing tasks have a positive effect, but the ability of students to use mathematics in their daily life is still in the low category, this has a positive effect but a negative result.

Finally, related to somatic symptoms, the percentage of students' responses is $65 \%$. The percentage of respondents with somatic statements is $84 \%$, for the motivation indicator using and assessing the relationship between mathematics and topics outside mathematics in applying the concept of perimeter and area of the triangle the answers given by respondents are $40 \%$, This percentage indicates that the student positively responds to the assignment given related to mathematical connection questions. However, when working on the assignment students experience difficulties due to somatic symptoms, it is proven that when given assignments to be done individually, students are quite enthusiastic and quite fast in collecting their assignments, however, students experience somatic symptoms, the results of the work are in accordance with the concept but not in accordance with the application of procedures in connecting. This means that the indicators of mathematics anxiety and the indicators of being diligent in facing tasks have a positive effect, but the ability of students to use and assess the relationship between mathematics and mathematics topics is still in a fairly good category. This has a positive effect, but the results are quite good.

In terms of the quality of the answers to each statement item related to somatic symptoms, the percentage of the student's response is $65 \%$ and the persistence indicator 
faces the difficulty of the answer given by the respondent, the percentage is $80 \%$ for the questions related to the ability to connect indicators to find relationships between various representations of concepts and procedures, and to understand The concept between mathematics topics obtained a total score from the answers given by respondents, a percentage of $40 \%$, this percentage indicates that students are serious when faced with difficulties, these difficulties arise due to somatic symptoms that make students afraid of mathematics, this can be seen when the teacher provides questions that must be resolved related to mathematical connection questions students are not able to understand the concepts of mathematical topics well as seen from the answers produced by students who answer questions that are not finished well. This means that somatic indicators and indicators of resilience in facing difficulties have a positive effect but the results of abilities. This had a positive effect but the results were quite good.

Indicators related to somatic symptoms of student response have a percentage of $65 \%$ and indicators of resilience in facing difficulties with answers given by respondents, the percentage is $80 \%$, for questions that have the equivalent representation of the same concept, looking for connections from one procedure to another in an equivalent representation, the answer is obtained. The percentage of respondents is $80 \%$, this percentage indicates that students are earnest when faced with difficulties, these difficulties arise due to fear of mathematics, this can be seen when the teacher gives questions that must be solved related to mathematical connection problems, students are able to understand The concept of an excellent mathematical topic can be seen from the answers that the students produce, the questions are finished well, even though they are still experiencing fear and uncertainty about the answers. This means that somatic symptoms can be minimized by being resilient when faced with difficulties so that the results obtained will be good too. This means that somatic indicators and resilience in facing tasks have a positive influence with positive results.

Furthermore, based on the students' answers related to somatic symptoms, the percentage of student responses was $65 \%$ and the indicator of resilience in facing difficulties with the answers given by the respondent's percentage was $80 \%$. This percentage indicates that students are very serious when faced with difficulties; this can be seen when the teacher gives questions that must be solved related to mathematical connection questions, students are not able to apply the concept of circumference, this 
can be seen from the students' answers that do not match this, due to the presence of significant somatic symptoms so that students were unable to solve the questions properly. This means that somatic indicators have a largely positive influence, and resilient indicators have a large positive effect but have a negative (low) result.

Based on students 'answers to statements related to somatic symptoms, the percentage of response to students' responses is $65 \%$ and indicators of resilience in facing difficulty in answers given by respondents, the percentage is $80 \%$, for using mathematics in other fields of study or daily life, the percentage of answers given by respondents is $25 \%$ This percentage indicates that students are very serious when faced with difficulties, difficulties in understanding mathematical material, this can be seen when researchers provide individual questions that must be solved related to mathematical connection problems, students are unable to relate questions to daily life. -this day can be seen from the students' answers that do not match in connecting the questions. This means that somatic indicators have a positive influence and resilient indicators have a positive effect, but the connection results are negative

Finally, the somatic symptom indicator of the response of students' responses is the percentage of $65 \%$ motivation to use and assess the linkage of mathematics between mathematical topics and topics outside mathematics in applying the concept of perimeter and area of the triangle of answers given by respondents, the percentage is $40 \%$ and the indicator of resilience in facing difficulties with answers given by respondents has a percentage of $80 \%$, this percentage indicates that students are very serious when faced with difficulties, this can be seen when researchers provide individual questions that must be solved related to mathematical connection questions, students feel able to apply the concept of circumference, this can be seen from the answers of students who not finished properly, but the students were wrong in linking the problems outside mathematics so that the students were wrong in concluding the results obtained.

In terms of the quality of the answers to each statement item related to somatic symptoms of student response responses, the percentage of $65 \%$ on indicators shows interest in various problems, $66.25 \%$ and questions related to the ability of the indicator connection look for relationships between various representations of concepts and procedures and understand The concept between mathematics topics obtained a total score from the answers given by respondents, a percentage of $40 \%$. This indicates that 
students have a high interest in learning but in learning students still experience difficulties because of fear of mathematics, but with interesting learning it provides an atmosphere more fun. This is shown at the time after the implementation of giving the questions individually connected to the student's answer connection, it shows that the students are not able to complete it well because students experience somatic symptoms, even though students have an interest in learning so that the results obtained are quite good. This means that it has a positive effect but with quite good results.

Indicators related to somatic symptoms of student response responses have a percentage of $65 \%$, and indicators on indicators showing interest in various problems, $66.25 \%$ of questions understand the equivalent representation of the same concept, looking for connections from one procedure to another in an equivalent representation, we get an equivalent answer. Given a percentage of $80 \%$ of respondents, this indicates that students have a high interest in learning even though significant somatic symptoms influence the learning process, but with interesting learning, it provides a more pleasant atmosphere. This is shown at the time after the implementation of giving the questions individually connected to the student's answer connection, which shows that students are able to complete it well. This means that even though it has a positive effect if it is able to minimize it well, the results will be good.

Furthermore, related to somatic symptoms, the percentage of student responses is $65 \%$ based on the students' answers to the questions using the relationship between conceptual representation and procedures in applying the concept of circumference, the percentage of answers given by respondents is $25 \%$ and the indicators show interest in various problems, $66.25 \%$ This indicates that students have a high interest in learning, interesting learning provides a more pleasant atmosphere. This is shown at the time after the implementation of giving individual questions related to the connection of the student's answers; it shows that the students are not able to solve them properly because the students are not able to apply the existing concepts and procedures so that the students' answers are not correct.

Based on students' answers to statements related to somatic symptoms, the percentage of student responses was $65 \%$ and the percentage of indicators showed interest in various problems, $66.25 \%$, in using mathematics in other fields of study or daily life, the percentage of answers given by respondents was $25 \%$. This indicates that students 
have a high interest in learning, but in learning, students still experience some somatic symptoms, which are quite significant but in their presence. This is shown at the time after the implementation of giving questions individually related to the connection of student answers; it shows that students cannot complete it properly because students cannot associate problem according to existing daily life so that the student's answer is not correct.

Finally, the somatic symptom indicator of the response of students' responses has a percentage of $65 \%$ and the indicators prefer to work independently $40 \%$, to use and assess the linkages of mathematics between mathematical topics and topics outside mathematics in applying the concept of the perimeter and area of the triangle the answers given by respondents are $40 \%$. This indicates that students have a high interest in learning but in learning students experience significant somatic symptoms. This is shown at the time after the implementation of giving individual questions related to the connection of student answers, it shows that students are not able to complete and use relationships outside mathematics properly so that the results obtained are not satisfactory.

In terms of the quality of the answers to each statement item related to somatic symptoms of student response responses, the percentage of $65 \%$ of indicators on indicators prefers to work independently with a percentage of $40 \%$ and questions related to the ability to connect indicators to find relationships between various representations of concepts and procedures and to understand concepts between topics Mathematics obtained a total score of the answers given by respondents with a percentage of $40 \%$, this indicates that students carry out connection questions online saying that it is better to work on the questions independently because according to him working with friends through online is not effective even though in the process the learning process of students still experiencing significant somatic symptoms. So, it can be said that students prefer to work independently to achieve better goals. This means that it has a positive influence

In the somatic symptom indicator, the percentage of the response of students is $65 \%$ and the percentage of $23.75 \%$ occurs in the indicator of getting bored quickly on routine tasks. Based on these percentages, students like learning with a new atmosphere; this is because according to the assumption of learning, students, which the teacher often applies, is always monotonous and boring. So when given questions related to 
mathematical connections students have difficulty linking, applying, and using existing concepts to affect student learning.

In the somatic symptom indicator, the percentage of students 'responses is $65 \%$. The percentage of students' responses is that the respondents have a percentage of $60 \%$. In this indicator, it can be seen in the learning process when competing to complete a mission that there are students who regret that they have followed their friends' opinions, which apparently did not give good results. It is clear that these students become more able to defend their opinions when working on math problems.

In the percentage of indicators of somatic symptoms, the percentage of response to students' answers is $65 \%$ and indicators regarding students are not easy to let go of things that are believed to increase by $80 \%$. This is the same as the indicator of being able to defend their opinion, students feel afraid if they experience failure again in solving connection questions. Therefore students are more consistent with what they have believed so that these results affect the ability of the connection with positive results.

The percentage of indicators of somatic symptoms in response to students' answers, the percentage of $65 \%$ of students being happy to find and solve complex problems, was $53 \%$. The percentage of this increase is seen from the enthusiasm of students when looking for and solving mathematical connection problems on a given mission, and not only that the enthusiasm of students in completing connections can be seen from the results of good answers with a fairly good score as well, it affects student connections. This means that it has a positive influence but with positive results. Based on the explanation of some of the indicators above, it can be seen that mathematics anxiety greatly affects the learning process of mathematics, but if there is motivation in learning grows with encouragement from within or outside, the motivation of students will be more enthusiastic. In learning, especially in connecting mathematics so that anxiety in mathematics can be minimized and students' mathematical connection skills will be better.

The results of this study are in line with the results of research conducted by Vivin et al. (2019) "Anxiety and Learning Motivation." It shows that the heavier the level of anxiety experienced by students, the worse the learning motivation and conversely the lighter the anxiety level, the higher the learning motivation. This study has an effect of $4.8 \%$ and the rest is affected by variables not examined by researchers. 
From the results of this study, it can be said that mathematics anxiety $\left(\mathrm{X}_{1}\right)$ and learning motivation $\left(\mathrm{X}_{2}\right)$ on the mathematical connection ability $(\mathrm{Y})$ has an effect of $30.3 \%$ in the sufficient category. This shows that in addition to mathematics anxiety and learning motivation, there are other factors that affect the ability of students to connect questions.

\section{CONCLUSION}

Based on the formulation of the problem and the research hypothesis, it can be concluded that there is an influence between mathematics anxiety on students' mathematical connection ability. The second conclusion is there is an influence between learning motivation on students' mathematical connection abilities. And, the last conclusion is there is an influence between mathematics anxiety and learning motivation on students' mathematical connection abilities.

Based on the research results and conclusions regarding the significant influence between mathematics anxiety on the mathematical connection ability of junior high school students, the suggestions in this study are as follows 1) it is necessary to do further research to find out the causes outside of the regression equation that affect the students' mathematical connections; and 2) provide a learning solution such as selecting methods, using media, or approaches to students during learning so that students' learning anxiety and motivation are better.

\section{REFERENCES}

Abade, E. A., Gonçalves, B. V, Silva, A. M., Leite, N. M., Castagna, C., Sampaio, J. E., Abdelrasoul, E., Mahmoud, I., Stergiou, P., Katz, L., Adler, J. J., Alaminos, D., Fernández, M. Á., Altmann, S., Ringhof, S., Neumann, R., Woll, A., Rumpf, M. C., Amani-Shalamzari, S., ... Akagi, R. (2019). All of a sudden, the Giants have bash and flash. PLOS ONE.

Am, S. (2011). Interaksi dan motivasi belajar mengajar. Jakarta: Raja Grafindo Persada. Anjani, D., \& Imami, A. I. (2020). Analisis Kemampuan Koneksi Matematis Siswa Smp Pada Materi Geometri. Prosiding Sesiomadika, 2(1a).

Badaruddin, Mustamin Anggo, dan Makkulau. (2019). Pengaruh Pendekatan Saintifik dan Pendekatan Realistic Mathematic Education (RME) Terhadapa Kemampuan Koneksi Matematis Ditinjau dari Motivasi Belajar Pada Siswa SMP. Jurnal Pembelajaran Berpikir Matematika, Vol. 4 No., 167-178. 
Dewi, W. A. F. (2020). Dampak COVID-19 terhadap Implementasi Pembelajaran Daring di Sekolah Dasar. Edukatif: Jurnal Ilmu Pendidikan, 2(1), 55-61. https://doi.org/10.31004/edukatif.v2i1.89

Hendriana, H., Rohaeti, E. E., \& Sumarmo, U. (2017). Hard skills dan soft skills matematik siswa. Bandung: Refika Aditama.

Hunsader, P. D., Thompson, D. R., \& Zorin, B. (2013). Engaging Elementary Students with Mathematical Processes During Assessment: What Opportunities Exist in Tests Accompanying Published Curricula? International Journal for Mathematics Teaching and Learning.

Kirkland, H. (2016). "Maths Anxiety": Isn't it just a dislike for learning mathematics? Mathematics Teaching.

Pizzie, R. G., McDermott, C. L., Salem, T. G., \& Kraemer, D. J. M. (2020). Neural evidence for cognitive reappraisal as a strategy to alleviate the effects of math anxiety. Social Cognitive and Affective Neuroscience. https://doi.org/10.1093/SCAN/NSAA161

Podkalicka, A. (2011). To Brunswick and Beyond: A Geography of Creative and Social Participation for Marginalised Youth. M/C Journal. https://doi.org/10.5204/mcj.367 Prayitno, A. (2018). Characteristics of Students' Critical Thinking In Solving Mathematics Problem. The Online Journal of New Horizons in Education.

Sancho-Vinuesa, T., \& Gras-Martí, A. (2010). Teaching and learning undergraduate mathematics in an online university. In Educational technology in practice: Research and practical case studies from the field.

Setiana, D. S., Ili, L., Rumasoreng, M. I., \& Prabowo, A. (2020). Relationship between Cooperative learning method and Students' Mathematics Learning Achievement: A Meta-Analysis Correlation. Al-Jabar: Jurnal Pendidikan Matematika. https://doi.org/10.24042/ajpm.v11i1.6620

Shuhan, J.-L. N. (2006). An interdisciplinary approach to secondary math class activities: The influence of multiple intelligences inspired tasks on student learning of geometric concepts. In ProQuest Dissertations and Theses.

Stuart, G. W. (2006). Buku Saku: Keperawatan Jiwa.

Sugiyono. (2016). Metode Penelitian Kuantitatif, Kualitatif, dan R\&D. Alfabeta.

Tobias, S. (1993). Overcoming math anxiety. WW Norton \& Company. 


\section{Hipotenusa Journal, 3 (1), June 2021}

Haerudin, Dewi Anjani, Didymus Ibrahi

Tomperi, P., Ryzhkova, I., Shestova, Y., Lyash, O., Lazareva, I., Lyash, A., Kvivesen, M., Manshadi, S., \& Uteng, S. (2020). The three-factor model: A study of common features in students' attitudes towards studying and learning science and mathematics in the three countries of the North Calotte region. LUMAT. https://doi.org/10.31129/LUMAT.8.1.1369

Utami, R., Roistika, N., Khoirot, U., Hanafi, M., \& Herminingsih, D. (2020). Teacher Professional Development in Education 4.0: Awareness of Digital Literacy. https://doi.org/10.4108/eai.13-2-2019.2286528 